\title{
POSSIPLE PROTECTIVE ROLE OF ASCORBIC ACID ON ETHANOL INDUCED TESTICULAR TOXICITY IN MALE ALBINO RATS
}

Sally M. Ahmed ${ }^{1}$, Marcell R. Harron ${ }^{\mathbf{1}}$, Nermeen A. M. Hassan ${ }^{\mathbf{1}}$, Abeer A. I. Sharaf El-Din ${ }^{\mathbf{1}}$, Sahar M. Abo El Wafa ${ }^{1}$ and Rania Z Amer ${ }^{2}$

${ }^{1}$ Department of Forensic Medicine and Clinical Toxicology

${ }^{2}$ Department of Pathology

Faculty of Medicine, Benha University, Benha, Egypt.

Corresponding author: Sally M. Ahmed, Department of Forensic Medicine and Clinical Toxicology, Faculty of Medicine, Benha University, Benha, Egypt, drsally85@hotmail.com,+2 01006299707

\begin{abstract}
Background: Exposure to ethanol results in many pathophysiologic changes in the function of the reproductive system caused by the alcohol itself and the effects of its metabolism in recurrent use. Ascorbic acid is a powerful antioxidant that can neutralize harmful compounds and potentiate the antioxidant capacity. Aim: this study was aimed to evaluate the protective effects of ascorbic acid against testicular changes caused by ethanol in adult male albino rats. Materials and Methods: Forty adult male rats were randomly distributed into four groups treated for 63 consecutive days, control group: was treated with distilled water only orally by gastric tube. Ascorbic acid group: was treated with ascorbic acid (100 mg/day/rat) dissolved in distilled water (dilution $50 \%$ ), once daily orally by gastric tube. Ethanol group: was treated with ethanol $(0.7 \mathrm{~g} / \mathrm{kg})$ dissolved in distilled water (dilution $50 \%$ ), once daily orally by gastric tube. Ethanol and ascorbic acid group: was treated with ethanol and ascorbic acid in the same previous doses orally by gastric tube. At the end of the study, rats were weighed then blood samples were obtained from each group to estimate the level of testosterone. Then the rats were sacrificed. The testes were dissected and weighed then used for evaluation of oxidative parameters (GSH and MDA), histopathological examination of testes by light and electron microscope. Results: Concomitant administration of ascorbic acid with ethanol resulted in a highly significant rise in body weight, with increase in mean testosterone level but this rise was insignificant, there was a highly significant decrease in MDA level and there was a highly significant increase in GSH level. Regarding histopathological results in the group of ascorbic acid with ethanol showed improvement in all histopathological changes induced by ethanol. As regard ultrastructure changes, microscopic examination in ethanol group revealed thickening of basement membrane, mitochondrial changes, degenerated spermatid with distorted acrosomal cap, with decrease in the sperm count results which were improved in the group of ascorbic acid with ethanol. Conclusion: oral administration of ethanol daily (50\% dilution) for 63 consecutive days in adult albino rats caused various testicular lesions which were significantly reduced with combined administration of ascorbic acid as an antioxidant.
\end{abstract}

Keywords: Ethanol, Testes, Ascorbic acid, Antioxidant.

\section{INTRODUCTION}

Alcohol is an organic compound that is widely used, mainly in western countries. It represents the oldest and the most used substance of abuse. Alcoholic beverages and the problems they produce have been known in human societies for a long time (Macdonald et al., 2010). 
Researchers have recognized alcohol use as a leading risk factor for diseases, and link

its consumption to sixty acute and chronic diseases. Diagnosis of toxic effect due to alcohol consumption is complicated due to the multiple mechanisms by which alcohol use affects health (Alcohol and Drug Use Collaborators, 2016).

Harmful substances like reactive oxygen species are created as a result of ethanol metabolism leading to cell injury and multiorgans failure as a result of ethanol abuse (Siervo et al., 2015).

Chronic alcohol use is known to produce toxic effects on the male reproductive system representing sexual dysfunction that may result in sterility with feminization (Harikrishnan et al., 2013).

Ascorbic acid is an electron donor and hence a reducing agent. All physiological or biochemical effects of ascorbic acid are contributed to its effect as an electron donor. Ascorbic acid is regarded as an antioxidant as it inhibits alternative compounds from oxidation by giving its electrons (Tripathi et al., 2009).

Ascorbic acid acts by guarding the body from reactive oxygen species and protect the cells from lipid peroxidation. Ascorbic acid also acts by neutralizing harmful substances in addition to renew other beneficial substances, like glutathione and vitamin E (Korkmaz and Kolankaya, 2009).

Ascorbic acid also acts by supporting the spermatogenesis by its ability to decrease the testicular oxidative stress produced by exposure to oxidants such as alcohol (Aitken and Roman, 2008).

\section{The aim of the work}

This study was carried out to estimate the toxic impact of ethanol consumption for 63 consecutive days on the testis of adult albino rats and the protective role of ascorbic acid against this toxicity.

\section{MATERIALS \& METHODS \\ I-Materials \\ - Chemicals, Dosage regimen and} vehicle:

A- Ethyl alcohol: Ethyl alcohol (CH3CH2OH) $100 \%$ purity was obtained from Sigma Aldrich Company (USA), it was available in liquid form, dissolved in distilled water (dilution $50 \% \quad(1: 1)$, and given in a dose of $0.7 \mathrm{~g} / \mathrm{kg}$ (representing $1 / 10$ of LD50,the oral median lethal dose (LD50) of ethanol in rats was $7060 \mathrm{mg} / \mathrm{kg}$ b.w. according to Lohr (2005) for 63 consecuative days which correspond to one spermatogenetic cycle .

\section{B- Ascorbic acid:}

Ascorbic acid (100\%) purity was purchased from EL-Gamhureia pharmaceutical and chemical company, Cairo, Egypt, available in powder form given in a dose $100 \mathrm{mg} /$ day/animal dissolved in distilled water (dilution 50\% (1:1). The selection of this dose was based on the previous study done by (Siervo et al., 2015).

\section{- Animals:}

Forty adult male albino rats, weighing between $300-320 \mathrm{~g}$ at the beginning of the experiment were included in this study. Rats were allowed for adaptation (1 week before experiments) at Anatomy Department, Faculty of Medicine, Benha University, to ascertain their physical wellbeing, and to exclude any diseased animals. All animals have received the same diet (wheat, bread \& milk) on a schedule of 12 hours of light and 12 hours of dark. The time of dose administration was fixed for all animals at 12 P.M.

\section{-Animal grouping:}

Forty adult male rats randomly divided into four groups, each consisted of 10 animals, and distributed as follows:

Group (I): (Control): Each rat was treated with distilled water and given orally by gastric tube. 
Group (II): (Ascorbic acid treated group): Each rat was treated with ascorbic acid (100 mg/day/animal) dissolved in distilled water (dilution 50\% (1:1), once daily and given orally by gastric tube.

Group (III): (Ethanol treated group): Each rat was treated with ethanol (0.7 $\mathrm{g} / \mathrm{kg}$ ) dissolved in distilled water (dilution $50 \%(1: 1)$, once daily and given orally by gastric tube.

Group (IV): (Ethanol \& Ascorbic acid group): Each rat was treated with ethanol $(0.7 \mathrm{~g} / \mathrm{kg})$ dissolved in distilled water (dilution50\% (1:1) and ascorbic acid (100 $\mathrm{mg} /$ day/animal) dissolved in distilled water (dilution50\% (1:1) once daily and given orally by gastric tube.

Animals were treated humanely according to the protocol of handling of experimental animals of Benha Faculty of Medicine and accepted by the Research Ethical Board of Faculty of Medicine, Benha University. Rats were sacrificed after 24 hours from the last administrated dose.

\section{II- Methods (study parameters) \\ 1-Weight of the body:}

Rats' body weights were measured at the beginning of the experiment (before treatment) and recorded, then at the end of the experiment using a sensitive balance.

2-Blood samples for biochemical analysis (Testosterone hormonal assay):

Rats were anesthetized with ether then blood samples were taken from the hearts. After that blood samples put in clean tubes without anticoagulant then left at $37^{\circ} \mathrm{c}$ incubator fifteen minutes. Coagulated blood centrifuged for fifteen minutes at $5000 \mathrm{rpm}$. Sera were put in the special tubes, covered by Parafilm, labeled and frozen for 3 days and tested after that for testosterone level measured by routine laboratory tests (radioimmunoassay) (Picard et al., 2008).

3-Testes weight
Testes were removed and stripped from their fatty tissues and blood vessels after scarification of rats at the end of the treatment and their relative weights were measured.

4- Tissue oxidative stress parameters:

A) Determination of Malondialdehyde (MDA) level :

Malondialdehyde level in tissue samples was determined using the method described by Chattopadhyay et al. (2003) , by measuring thiobarbituric reactive species. The thiobarbituric acid reactive substances react with thiobarbituric acid to creat a pink color, which can readed colorimetrically at $532 \mathrm{~nm}$. Lipid peroxidase expressed as malondialdehyde (MDA), was determined in the supernatant using commercially available colorimetric methods (diagnostic kits supplied by Biodiagnostic; Dokki, Giza, Egypt) following the manufacturer instructions.

B) Determination of the level of Reduced Glutathione (GSH) :

The GSH concentration in tissue samples was determined using the method described by Siervo et al.( 2015). The levels determined by 5,5 dithiobis- 20nitrobenzoic acid in testes \& epididymis homogenate supernatant \& confirmed with yellow color which measured at $412 \mathrm{~nm}$. Reduced glutathione level was determined in the supernatant using commercially available colorimetric methods (diagnostic kits supplied by Biodiagnostic; Dokki, Giza, Egypt) following the manufacturer instructions.

5- Histopathological study (light and electron microscope):

A) Light microscope

According to Bancroft and Gamble (2008) testes soaked in bouin's solution, which is used to fix organs that need good morphologic analysis like testis. Tissue specimens were fixed for 6- 8 hours and 
then transferred to $70 \%$ alcohol before submitting to histology for automated dehydration, paraffin embedding, sectioning, and staining at Pathology Department, Faculty of Medicine, Benha University.

\section{B) Electron microscope:}

According to Maunsbach and Afzelius (1999) small pieces of testes fixed in $2.5 \%$ glutaraldehyde buffered with 0.1 M cacodylate ( $\mathrm{pH} \mathrm{7.2)} \mathrm{for} \mathrm{two} \mathrm{hrs.} \mathrm{The}$ specimens washed 3 times with the same buffer and post-fixed in phosphatebuffered $1 \%$ osmium tetroxide for two hrs at room temperature then dehydrated in ascending grades of ethanol. After immersion in propylene oxide, specimens embedded in epoxy resin mixture. Semithin sections (1 um thick) were obtained and stained with $1 \%$ toluidine blue and examined by light microscope. Ultrathin sections $(80-90 \mathrm{~nm})$ were cut by LKB ultratome and stained with uranyl acetate and lead citrate. The ultrastructural analysis was done with a transmission electron microscope ( TEM )at Tanta University.

\section{Statistical analysis}

The data had recorded, put in tables then analyzed using SPSS (Statistical package for social science) version 20. Data were presented as mean and standard deviation for quantitative data, frequency, and distribution for qualitative data. They were tested using ANOVA test ( $\mathrm{F}$ value) used to compare mean of more than two groups of quantitative data with using post hoc test( LSD) for inter-group comparison, corrected chi-square test (Fisher Exact Test) (FET) used for Inter-group comparison of categorical data. The accepted level of significance in this work was started at $0.05 \quad(\mathrm{P}<0.05$ was considered significant) (Greenberg et al., 1996).

\section{RESULTS}

\section{-The body weight and relative weight of testis:}

As regarding body weight, there was no significant difference between mean body weight of control and ascorbic acid treated groups, while ethanol group showed a significant decrease in mean body weight, which was greatly improved by increase in body weight in (ethanol and ascorbic acid group) (Table 1). There was no significant difference between all studied groups regarding the relative weight of testis (Table 2).

Table (1): Statistical comparison between all studied groups regarding final body weight by ANOVA test.

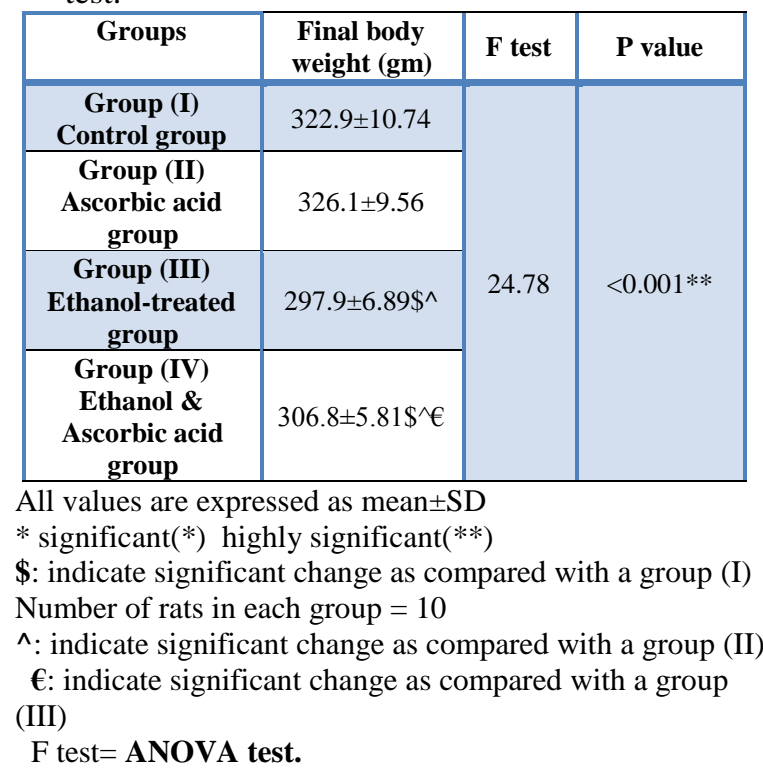

Table (2): Statistical comparison between all studied groups regarding the relative weight of the testis by ANOVA test.

\begin{tabular}{|c|c|c|c|}
\hline Groups & $\begin{array}{c}\text { The relative weight } \\
\text { of the testis } \\
\text { (RW\%) }\end{array}$ & $\begin{array}{c}\text { F } \\
\text { test }\end{array}$ & P value \\
\hline $\begin{array}{c}\text { Group (I) } \\
\text { Control group }\end{array}$ & $0.53 \pm 0.073$ & \multirow{2}{*}{0.96} & \multirow{2}{*}{0.42} \\
\hline $\begin{array}{c}\text { Group (II) } \\
\text { Ascorbic acid group }\end{array}$ & $0.55 \pm 0.075$ & \\
\hline $\begin{array}{c}\text { Group (III) } \\
\text { Ethanol-treated } \\
\text { group }\end{array}$ & $0.49 \pm 0.068$ & \\
\hline $\begin{array}{c}\text { Group (IV) } \\
\text { Ethanol\& ascorbic } \\
\text { acid group }\end{array}$ & $0.52 \pm 0.079$ & & \\
\hline
\end{tabular}

All values are expressed as mean \pm SD

Number of rats in each group $=10$

$\mathrm{F}$ test $=$ ANOVA test. 


\section{-Biochemical results:}

\section{1-Testosterone hormone level:}

The results showed that no significant difference was founded between the testosterone level in both the control group and ascorbic acid group, while there was a highly considerable decrease in mean testosterone level in the ethanol-treated group, while concomitant use of ascorbic acid with ethanol in (Ethanol\& ascorbic acid) group resulted in an increase in mean testosterone level but this rise was insignificant (Table3).

Table (3): Statistical comparison between all studied groups regarding testosterone hormone level by ANOVA test.

\begin{tabular}{|c|c|c|c|}
\hline Groups & $\begin{array}{c}\text { Testosterone } \\
\text { hormone level } \\
\text { (ng/ml) }\end{array}$ & $\begin{array}{c}\text { F } \\
\text { test }\end{array}$ & $\begin{array}{c}\text { P } \\
\text { value }\end{array}$ \\
\hline $\begin{array}{c}\text { Group (I) } \\
\text { Control } \\
\text { group }\end{array}$ & $1.48 \pm 0.34$ & & \\
\cline { 1 - 2 } $\begin{array}{c}\text { Group (II) } \\
\text { Ascorbic } \\
\text { acid group }\end{array}$ & $1.59 \pm 0.29$ & \multirow{0}{*}{3.28} & \\
\cline { 1 - 2 } $\begin{array}{c}\text { Group (III) } \\
\text { Ethanol- } \\
\text { treated } \\
\text { group }\end{array}$ & $1.20 \pm 0.28 \$^{\wedge}$ & & \\
\cline { 1 - 2 } $\begin{array}{c}\text { Group (IV) } \\
\text { Ethanol \& } \\
\text { Ascorbic } \\
\text { acid group }\end{array}$ & $1.32 \pm 0.29^{\wedge}$ & & \\
\hline
\end{tabular}

All values are expressed as mean \pm SD

Number of rats in each group $=10$

$\$$ : indicate significant change as compared with a group (I) significant $(*)$

^: indicate significant change as compared with a group (II)

$€$ : indicate significant change as compared with a group (III)

$\mathrm{F}$ test $=$ ANOVA test.

\section{2-Oxidative stress parameters result:}

As regarding mean Malondialdehyde (MDA) level, there was a considerable decrease in MDA level in ascorbic acid group when compared to the control group, while ethanol administration resulted in highly significant increase in MDA level when compared to both the control and ascorbic acid group. Concomitant administration of Ascorbic acid with ethanol in the (ethanol\&ascorbic acid) group resulted in great improvement representing in a highly significant decrease in MDA level as compared with ethanol treated group (Table 4).
Table (4): Statistical comparison between all studied groups regarding malondialdehyde (MDA) level by ANOVA test.

\begin{tabular}{|l|c|c|c|}
\hline Groups & MDA level & \multicolumn{1}{|c|}{$\begin{array}{c}\text { F } \\
\text { test }\end{array}$} & P value \\
\hline $\begin{array}{l}\text { Group (I) } \\
\text { Control group }\end{array}$ & $25.99 \pm 3.61$ & & \\
\cline { 1 - 2 } $\begin{array}{l}\text { Group (II) } \\
\text { Ascorbic acid group }\end{array}$ & $22.15 \pm 3.46$ & \multirow{2}{*}{77.01} & $\mathbf{0 . 0 0 1 * *}$ \\
\cline { 1 - 2 } $\begin{array}{l}\text { Group (III) } \\
\text { Ethanol-treated } \\
\text { group }\end{array}$ & $48.63 \pm 4.57 \$^{\wedge}$ & & \\
\cline { 1 - 2 } $\begin{array}{l}\text { Group (IV) Ascorbic } \\
\text { Ethanol\& } \\
\text { acid group }\end{array}$ & $27.14 \pm 5.33^{\wedge} €$ & & \\
\hline
\end{tabular}

All values are expressed as mean \pm SD

Number of rats in each group $=10$

\$: indicate significant change as compared with a group (I) significant $(*)$ highly significant $(* *)$

$\wedge$ : indicate significant change as compared with a group (II)

$€$ : indicate significant change as compared with a group (III)

$\mathrm{F}$ test $=$ ANOVA test.

Regarding GSH level, there was a highly significant rise in GSH level in ascorbic acid treated rats as compared to control group, ethanol administration resulted in highly significant decrease in GSH level as compared to control and ascorbic acid group. Administration of ascorbic acid with ethanol lead to highly significant increase in GSH level when compared with control and ethanol treated group (Table 5).

Table (5): Statistical comparison between all studied groups regarding reduced gutathione (GSH) level by ANOVA test.

\begin{tabular}{|c|c|c|c|}
\hline Groups & $\begin{array}{c}\text { GSH level } \\
(\mathrm{mg} / \mathrm{g})\end{array}$ & $\begin{array}{c}\text { F } \\
\text { test }\end{array}$ & P value \\
\hline $\begin{array}{c}\text { Group (I) } \\
\text { Control group }\end{array}$ & $122.42 \pm 5.25$ & \multirow{4}{*}{23.76} & \multirow{4}{*}{$0.001 * *$} \\
\hline $\begin{array}{c}\text { Group (II) } \\
\text { Ascorbic acid group }\end{array}$ & $178.32 \pm 24.12 \$$ & & \\
\hline $\begin{array}{c}\text { Group (III) } \\
\text { Ethanol-treated } \\
\text { group } \\
\end{array}$ & $91.83 \pm 9.04 \$^{\wedge}$ & & \\
\hline $\begin{array}{l}\text { Group (IV) } \\
\text { Ethanol \& Ascorbic } \\
\text { acid group }\end{array}$ & $169.33 \pm 45.72 \$ €$ & & \\
\hline
\end{tabular}

All values are expressed as mean \pm SD

Number of rats in each group $=10$

$\$$ : indicate significant change as compared with a group (I)

$\wedge$ : indicate significant change as compared with group (II)

$€$ : indicate significant change as compared with a group (III)

significant $(*)$ highly significant $(* *)$

F test $=$ ANOVA test. 


\section{-Histopathological finding:}

\section{A) Light microscope results}

Both control and ascorbic acid groups showed preserved architecture with well arranged seminiferous tubules, histopathological changes in ethanol-treated rats were representing in prominent interstitial edema, interstitial hemorrhage, venous congestion, distortion of the architecture of seminiferous tubules distorted germ cells and vacuolization of cells, these changes were greatly improved in (ethanol \&ascorbic acid group) (Figs. 1,2).

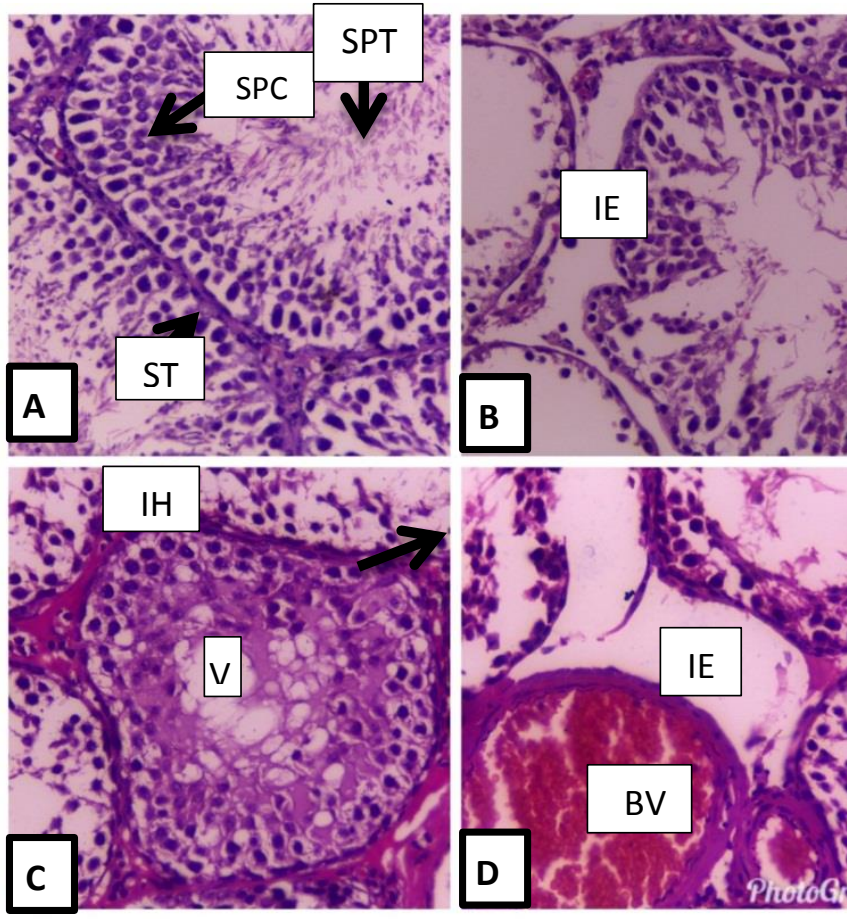

Fig.(1): Comparison between control group and ethanol treated group regarding histopathological changes (H\&E x 400)

A: Photomicrograph of a section in rat's testis prepared from a control rat showing the seminefrous tubule contains sertoli cells(ST), spermatogonia(SG), spermatocyte(SPC),spermatid(SPT) and leidyg cell(L)within interstitial tissue(H\&Ex 400).

B: A photomicrograph of a section in rat's testis prepared from ethanol- treated rat showing interstitial edema (I) with congested blood vessel(BV), seminefrous tubules(S) showed degeneration of germ cells with decrease in spermatid (SPT) count (H\&E x 400).

C: A photomicrograph of a section in rat's testis prepared from ethanol- treated rat showing disrupted architecture of seminefrous tubules with extensive intercullar vaccuoles(V) and interstitial hemorrhage (IH) (H\&E x 400)

D: A photomicrograph of a section in rat's testis prepared from ethanol- treated rat showing disruption of basement membrane(BM) of sertoli cell with degenerated germ cell $(\mathrm{G})$, extensive interstitial edema (I) with dilated congested blood vessel (BV) (H\&E x 400).

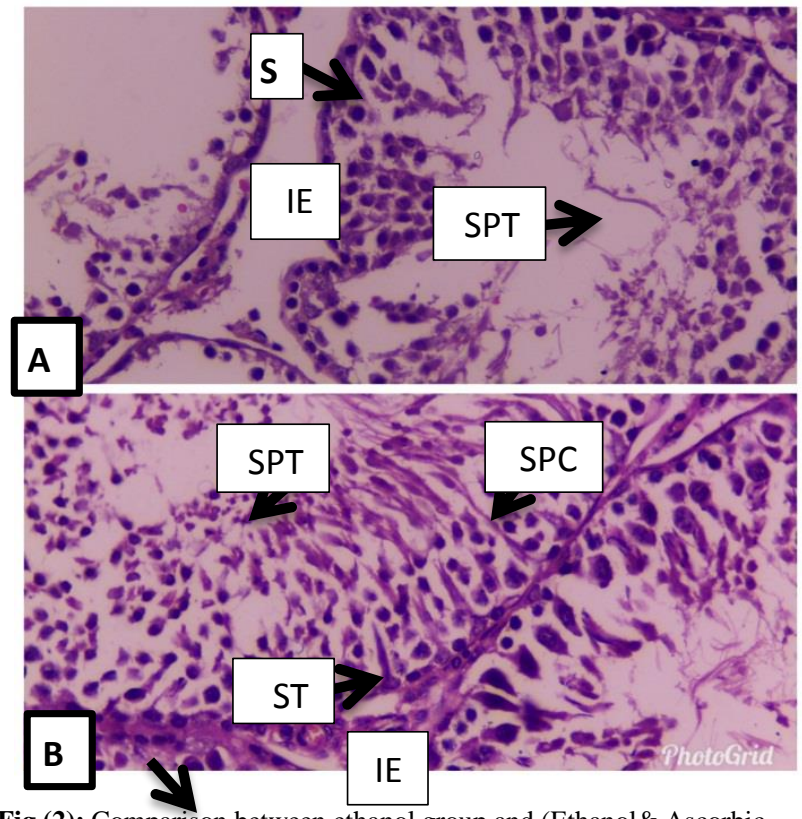

Fig.(2): Comparison between ethanol group and (Ethanol\& Ascorbic acid) group regarding histopathological changes (H\&E x 400)

A: A photomicro section in rat's testis prepared from ethanol- treated $\mathrm{r}$ SPT g interstitial edema (IE), seminefrous tubules(S) show cells with decrease in spermatid (SPT) bount (H\&E x 400).

B: A photomicrograph of a section in rat's testis prepared from ethanol\& vit.C group showed normal architecture of seminefrous tubules with normal sertoli (ST) cell, spermatocyte (SPC) and spermatid (SPT) with minimal interstitial edema(IE) and no vacuolization (H\&E x 400)

\section{B) Electron microscope results:}

Both control and ascorbic acid treated groups IE $\mathrm{d}$ normal histological finding while ctrranol group showed many abnormalities representing in thickening of basement membrane, nuclear invagination, swollen disrupted mitochondria with appearance of autophagic vacuoles within sertoli cells, spermatogonia with degenerated chromatin, spermatocyte with cytoplasmic vacuolation and distorted acrosomal cap, degenerated spermatid, with appearance of dense bodies and shedding of cells in the lumen, leidyg cells with cytoplasmic vacuolation. Tubular lumen was smaller than normal with a decrease in the sperm count (Figs. 3-12). 


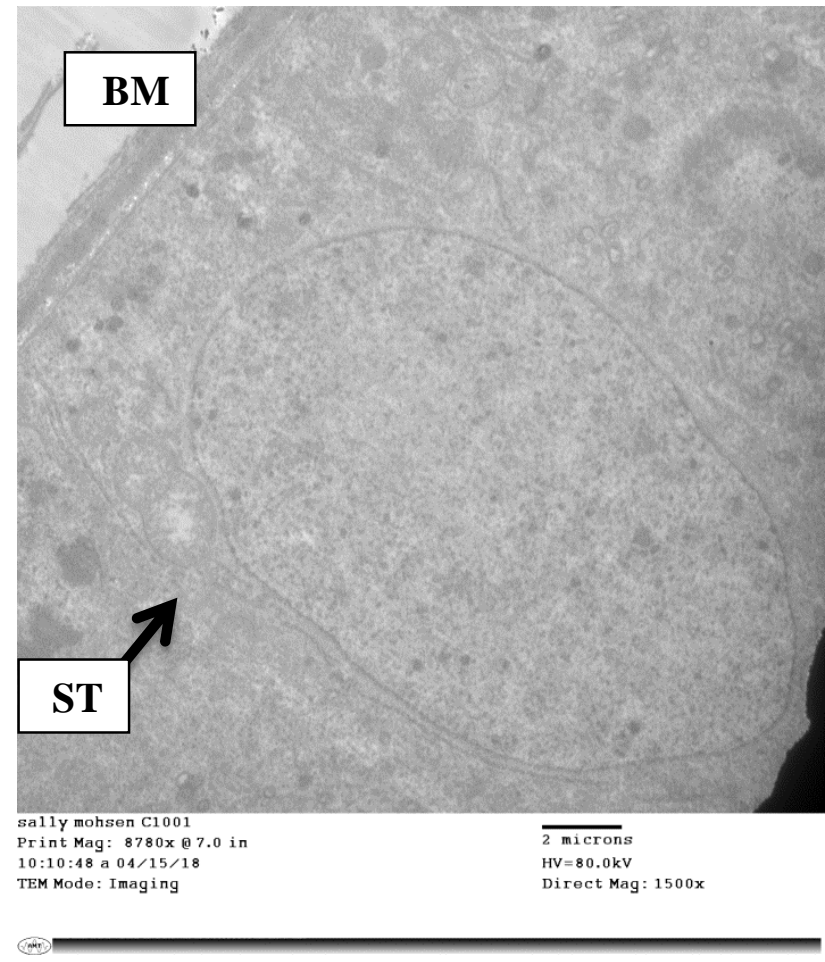

Fig. (3): An electron photo micrograph of a section from the testis of a control rat showing normal basement membrane (BM) \& Sertoli cell (ST) (OM X 1500)

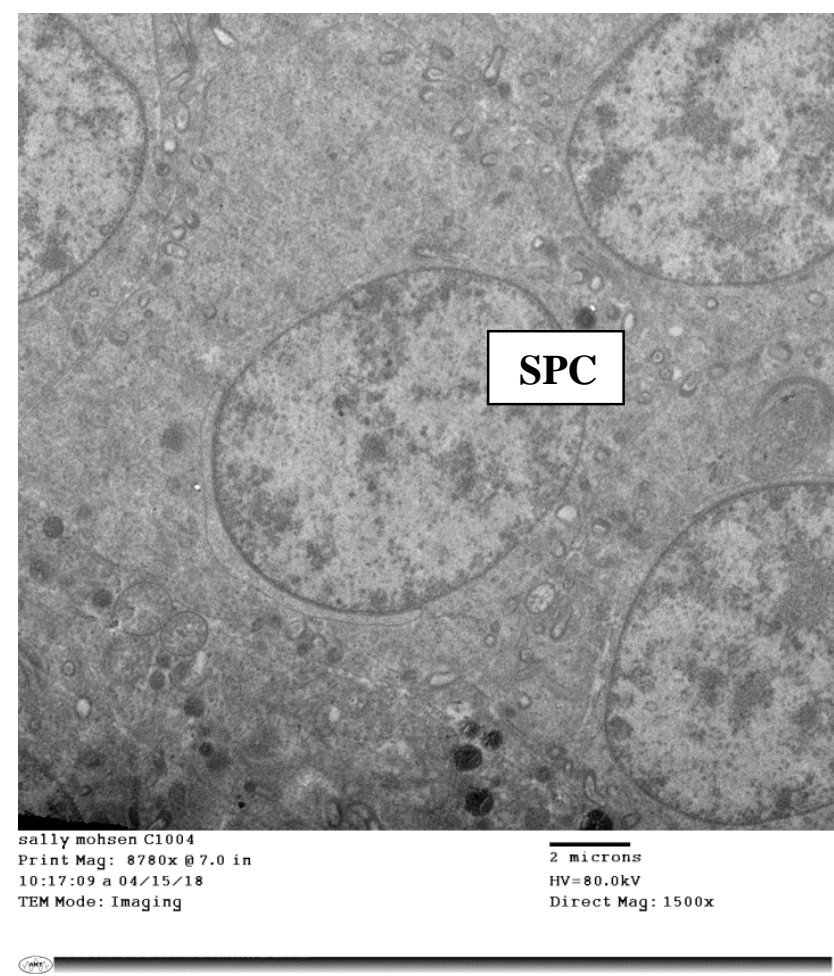

Fig. (4): An electron photo micrograph of a section from the testis of acontrol rat showing normal spermatocyte (SPC) with start the development of acrosomal cap (OM X 1500)

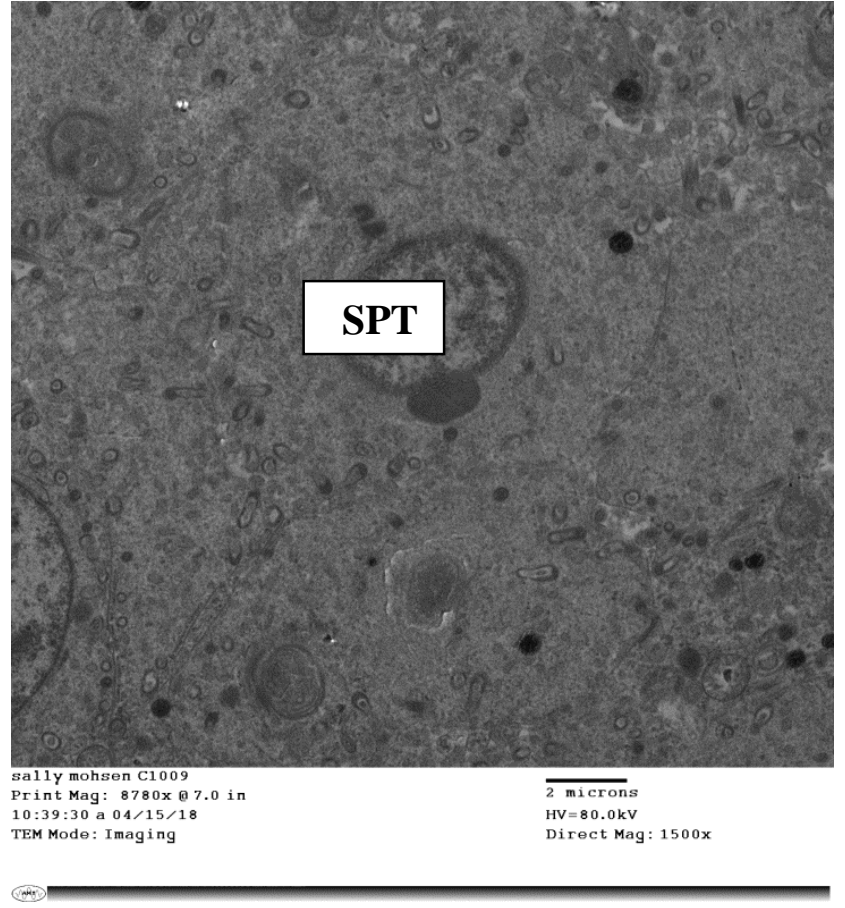

Fig. (5): An electron photo micrograph of a section from the testis of a control rat showing normal spermatid (SPT) (OM X 1500)

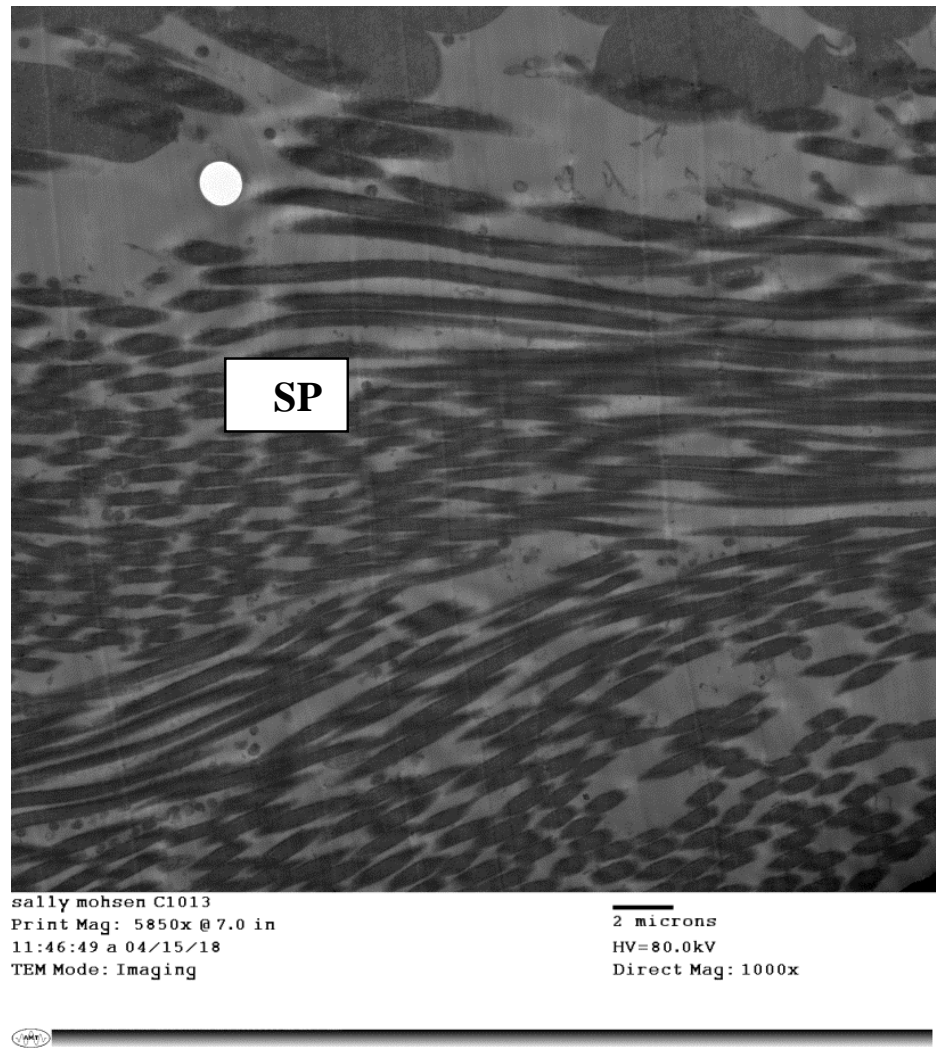

Fig. (6): An electron photo micrograph of a section from the testis of a control rat showing wide tubular lumen full of sperms

$(\mathrm{SP})(\mathrm{OM} \times 1000)$ 


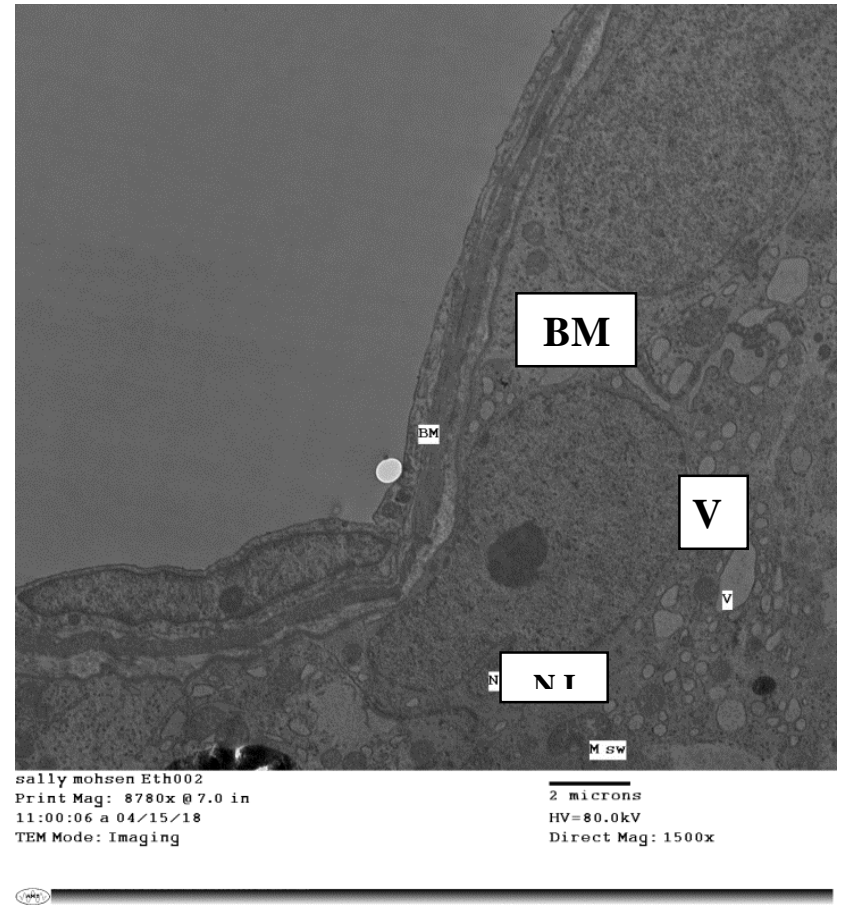

Fig.(7):An electron micrograph of a section taking from the testis of ethanol treated rat group showing thickening of basement membrane (BM), nuclear invagination(NI), mitochondrial swelling(MS) of Sertoli cell, with appearance of autophagic vacuoles (V) (OM X 1500).

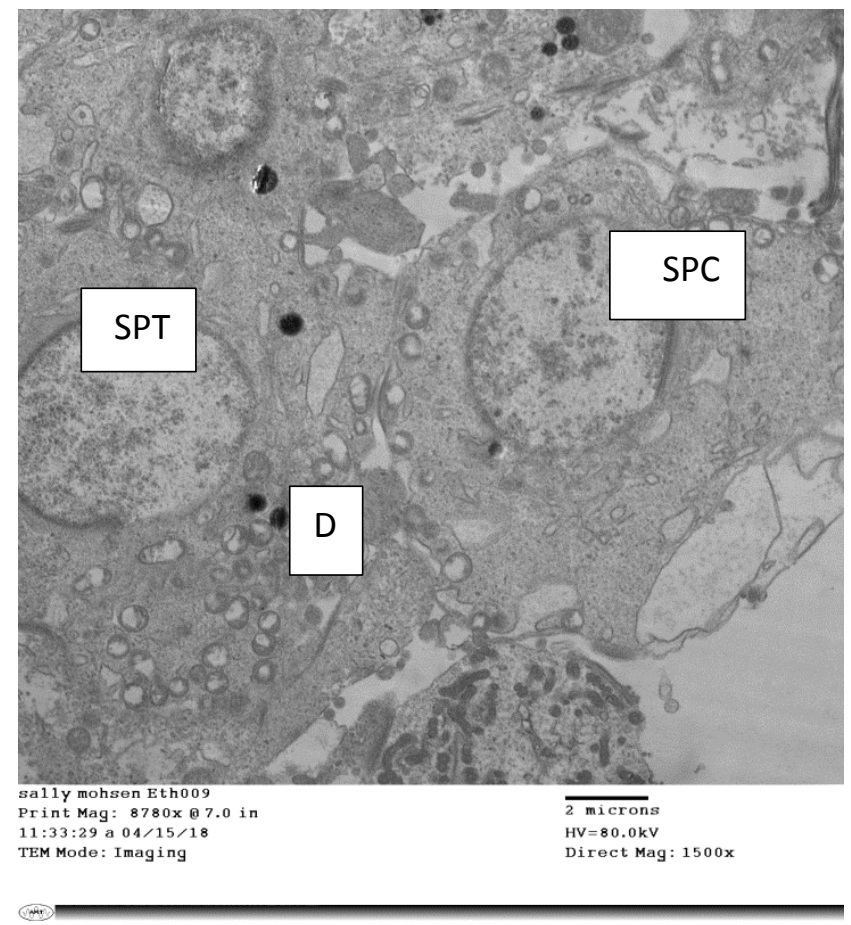

Fig. (8): An electron photo micrograph of a section taking from the testis of ethanol treated rat group showing secondary spermatocyte (SPC) with swollen sequestered mitochondria, degenerated spermatid (SPT) with distorted acrosomal cap, appearance of dense bodies (D) and shedding of cells in the lumen (OM X1500)

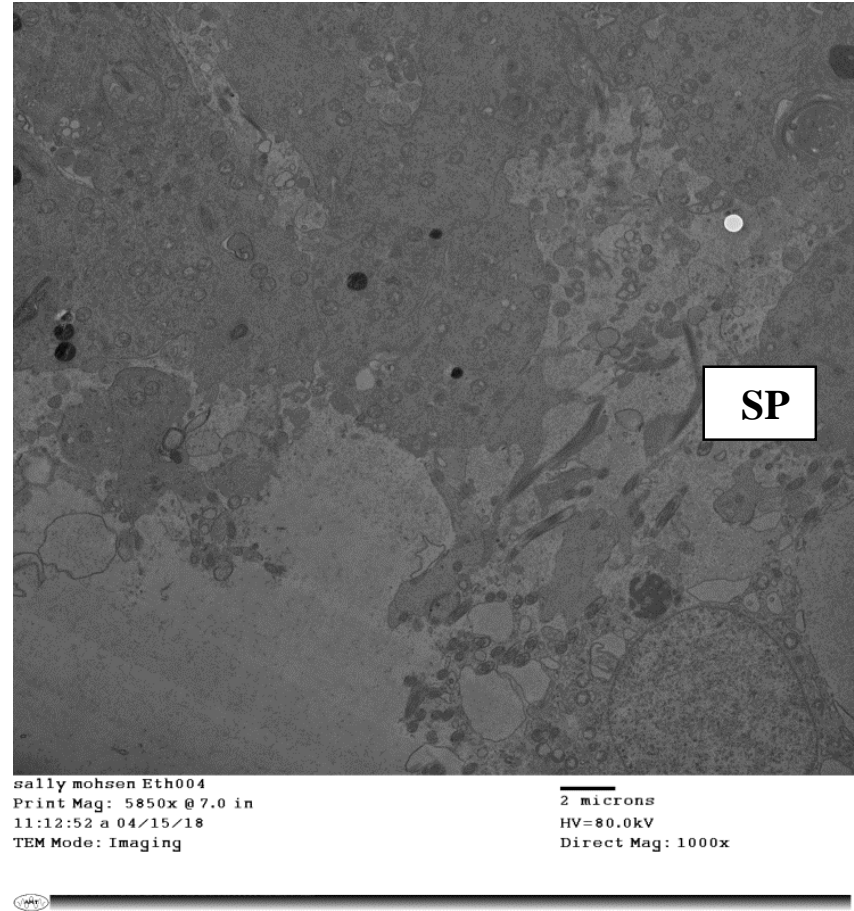

Fig. (9): An electron photo micrograph of a section taking from the testis of ethanol treated rat group showing tubular lumen smaller than control with decrease in the sperm (SP) count (OM X1000)

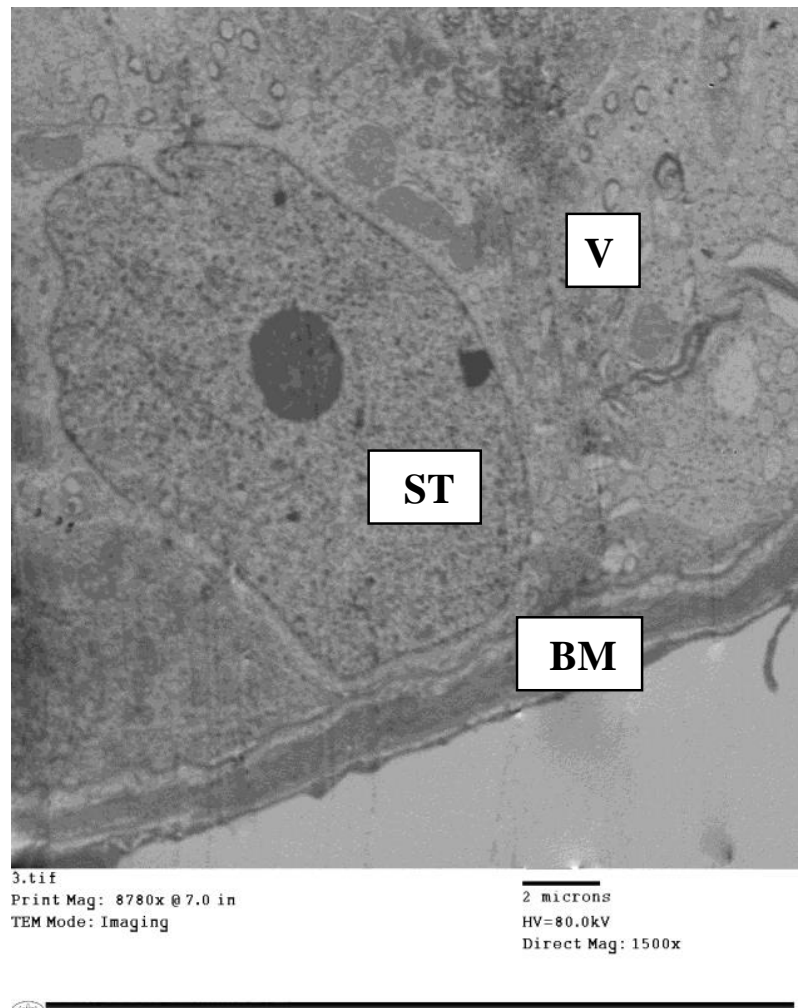

Fig.(10): An electron photo micrograph of a section taking from the testis of ethanol\&Ascorbic group (IV) showing normal basement membrane (BM) and Sertoli cell (ST) with decrease in the number of autophagic vacuoles (V) (OM X 1500). 


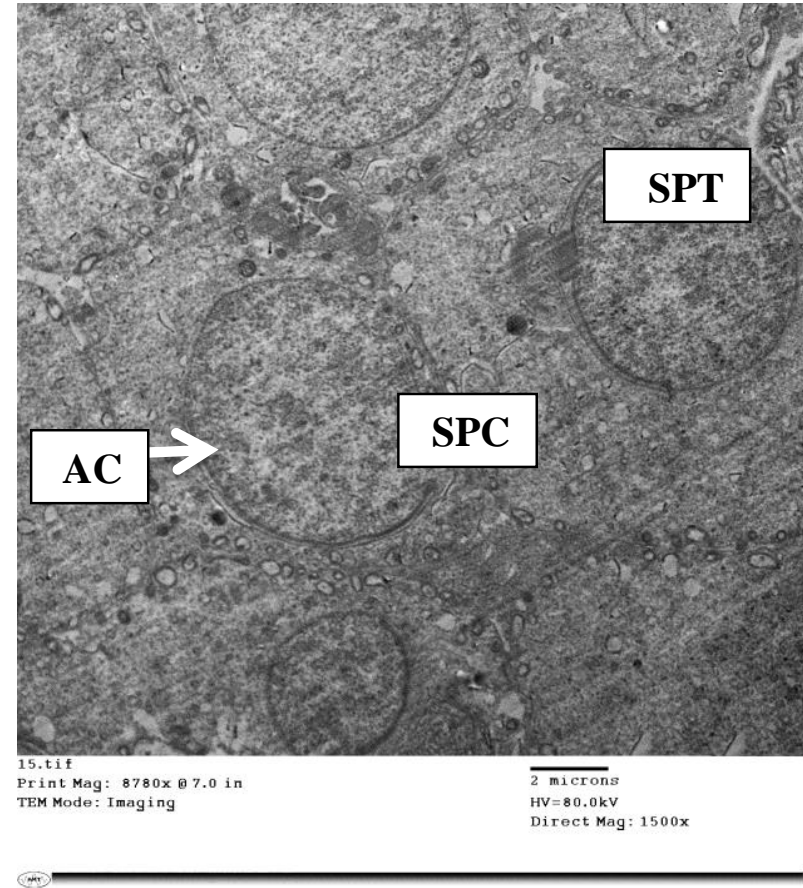

Fig. (11): An electron photo micrograph of a section taking from the testis of ethanol\&Ascorbic acid group (IV) showing normal secondary spermatocyte (SPC) with well developed acrosomal cap (AC) and normal spermatid (SPT) with decrese in the intercellular space and autophagic vacuoles (OM X 1500).

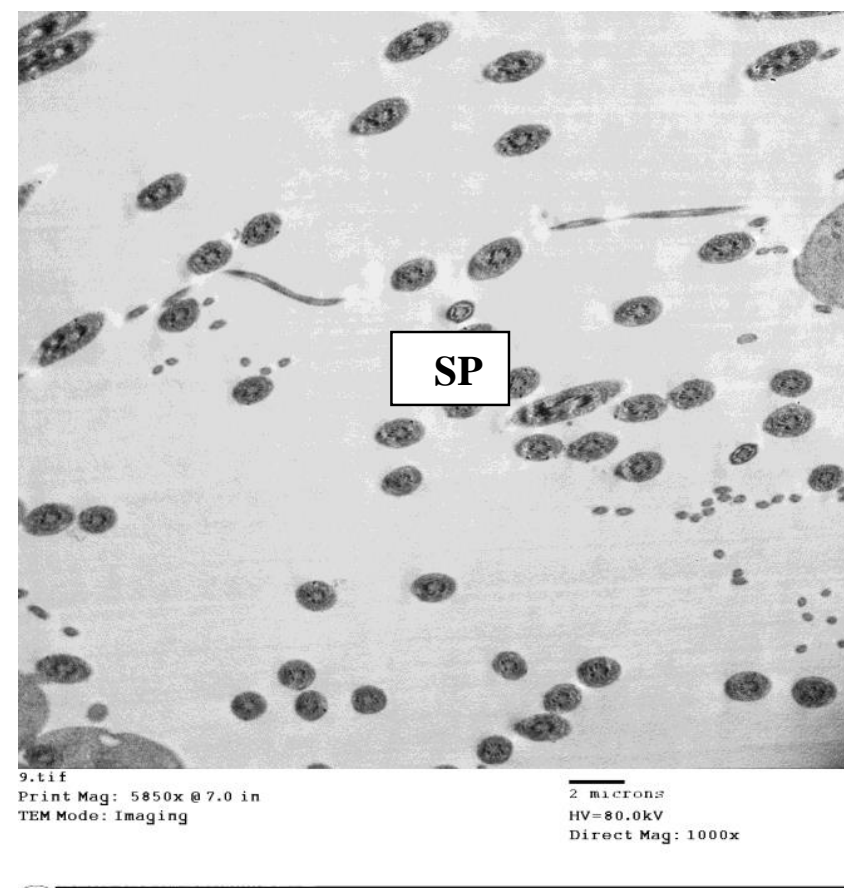

Fig. (12): An electron photo micrograph of a section taking from the testis of ethanol\&Ascorbic acid group showing transverse section of tubular lumen showing increase in the sperm (SP) count than ethanol treated group(OM X 1000)

\section{DISCUSION}

Alcohol is extensively used in alcoholic drinks everywhere in the world. There is an increase in alcohol abuse more than before leading to increases in morbidity and mortality around the world due to alcohol-related disorders (Macdonald et al., 2010).

Ascorbic acid has the ability to reduce harmful substances like ROS and protect the testes against them. Ascorbic acid has an important effect on semen integrity and fertility, in a human being or experimental animals, and responsible for about sixtyfive percent of the total antioxidant character of seminal plasma present inside or outside the cell (Harikrishnan et al., 2013).

Regarding body weight, our results showed that ethanol administration resulted in highly significant decrease in the body weight as compared to control and ascorbic acid group, at the same time concomitant administration of ascorbic acid with ethanol resulted in great improvement manifested by a highly significant rise in body weight as compared to ethanol group.

This reduction in body weight may be due to the action of alcohol on nutrient absorption by damaging gastric and intestinal cells and prevent transport of nutrients to the blood. Alcohol prevents the degradation of foods into useful substances, by diminishing the excretion of digestive enzymes from pancreas (Macdonald et al., 2010).

Shalan et al.(2007) study agreed with our result as it showed that there was a significant reduction in the body weight which reached its maximum value $(-20 \%)$ after two weeks of alcohol intake. The degree of the reduction in body weight was increased after that by prolonged ethanol intake. This reduction in body weight was 
due to the action of ethanol on food intake and decrease feed adequacy.

Macdonald et al. (2010) study agreed with our result as it showed a significant decrease in the body weight of rats given ethanol comparing by the control group.

On the other hand, Siervo et al. (2015) found that no significant difference in the body weight between rats of control group, ethanol-treated group and ascorbic acid group.

Regarding relative weight of testes, the results of the present study revealed no significant change in testes weight between all studied groups.

Siervo et al. (2015) study also agreed with our result as it showed no difference between control, ethanol-treated and ascorbic acid protected group.

Ebugosi et al. (2017) revealed significant reduction $(\mathrm{P}<0.05)$ in the mean weights of the testes in the test groups compared with control in all weeks under study.

Regarding testosterone result, our study showed a significant decrease in testosterone level after 63 days of ethanol administration when comparing it with the control group, while in ethanol group with ascorbic acid, there is a mild insignificant improvement in testosterone level.

The decrease in testosterone level may be due to that ethanol increase protein catabolism causing muscle atrophy and testicular atrophy which is associated with a decrease in testosterone level.

Takeda et al. (2003) study coincides with our result, as its result showed a significant decrease in testosterone level after ethanol administration.

Siervo et al. (2015) result showed a non-significant decrease in testosterone level after ethanol administration and remain unchanged after protection with ascorbic acid.
As regarding mean malondialdehyde (MDA) level, our study showed that there was considerable decrease as regarding malondialdehyde concentration on ascorbic acid group as compared to control group, while ethanol administration resulted in highly considerable increase in MDA level as compared to both control and ascorbic acid group. Concomitant administration of ascorbic acid with ethanol in the combination group resulted in great improvement representing a highly significant decrease in MDA level as compared with ethanol-treated group.

The increase in the level of MDA showed in testes may be attributed to the formation of free radicals liberated from the conversion of ethanol by alcohol dehydrogenase enzyme to toxic acetaldehyde, resulted in the peroxidation process and cell damage (Macdonald et al., 2010).

Waly et al. (2015) study showed that adequate intake of ascorbic acid every day in healthy young adults resulted in a great decrease of MDA level.

Harikrishnan et al. (2013) showed a significant increase in the MDA level in the ethanol-administrated group as compared to the control, which decreased by ascorbic acid intake.

Macdonald et al. (2010) study agreed with our result as it showed significant increase in MDA level after 28 days of ethanol administration as compared with the control group.

Regarding GSH level, our study showed that there was a highly significant rise in GSH level in ascorbic acid treated rats as compared to control group, while ethanol administration resulted in highly significant decrease in GSH when compared with control and ascorbic acid group. Administration of ascorbic acid with ethanol leads to a highly significant 
increase in GSH level in relation to the control \& ethanol-treated group.

Ethanol induced depletion of glutathione supports the hypothesis that reactive oxygen intermediates generated during the metabolism of ethanol lead to glutathione oxidation and lipid peroxidation and are responsible for the toxic effects of ethanol (Maneesh et al., 2005).

Fernandes et al. (2011) study the antioxidant ability of ascorbic acid on the reproductive system of the hyperglycemic rats, and the result showed a significant increase in GSH level in ascorbic acid treated group when compared to the control group.

Adequate intake of ascorbic acid every day in animal or human leads to an increase in GSH (Waly et al., 2015).

Mirzaei et al. (2015) study also agreed with our study as it showed that consumption of ethanol in rats after 12 weeks causes a significantly decreased in reduced glutathione concentration in the ethanol-treated group compared to control group, this decrease in GSH level due to the pathogenic role of oxidative stress which presents in chronic ethanol consumption.

Siervo et al. (2015) study disagreed with our study as their results showed no significant difference in GSH level between control, ethanol-treated and ascorbic acid protective group.

Regarding histopathological results, our results showed that testes exposed to ethanol for 63 consecutive days, showed prominent changes including interstitial edema, interstitial hemorrhage, and venous congestion, distortion of the architecture of seminiferous tubules, distorted germ cells, and vacuolization of cells while concomitant use of ascorbic acid with ethanol in the group showed improvement in all histopathological finding.
Dosumu et al. (2014) studied histopathological alterations in the testes following eight weeks of ethanol administration and the study revealed a significant decrease in cells of the spermatogenic type, hypocellularity in the interstitium, expansion of the tubular lumen, tubular atrophy and decrease spermatozoa count.

Our result as regard ultrastructure changes, microscopic examination of the testicular specimens in ethanol group revealed thickening of basement membrane, Sertoli cells with nuclear invagination, mitochondrial swelling and appearance of autophagic vacuoles, spermatogonia with degenerated chromatin, swollen disrupted mitochondria, spermatocyte with swollen sequestered mitochondria and vacuolation, degenerated spermatid with distorted acrosomal cap, appearance of dense bodies and shedding of cells in the lumen, abnormal leidyg cells with cytoplasmic vacuolation, tubular lumen smaller with decrease in the sperm count as compared to the control group.

These changes mean that testicular energy was affected by chronic ethanol use lead to a decrease in the ability of the mitochondria to do mitochondrial protein synthesis due to changes in mitochondrial ribosomes which makes them less functional. This results in a decrease in the translation of the oxidative phosphorylation associated polypeptides leading to enzyme inactivation leading to changes in the mitochondria which may activate apoptotic and necrotic cell death, resulting in the continuous testicular damage due to ethanol use (Dosumu et al., 2014).

Eid et al. (2012) studied the effect of ethanol intake for 12 weeks on ultrastructure of sertloi cells and revealed highly vacuolization of sertoli cells in 
ethanol-treated rats and sequestration of mitochondria into autophagic vacuoles, which means activation of mitophagy which is thought to be a survival route recognized by formation of membranes, that isolate an area of cytoplasm or damaged organs like mitochondria, to form autophagosomes. Then the autophagosomes fuse with lysosomes forming autolysosomes, where their contents digested by lysosomal enzymes.

\section{CONCLUSION}

From the results of current study, it is concluded that oral administration of ethanol daily $(0.7 \mathrm{~g} / \mathrm{kg} /$ day) ( $50 \%$ dilution $1 \mathrm{ml}$ ethanol: $1 \mathrm{ml}$ of distilled water) for 63 consecutive days in adult albino rats, caused various testicular lesions which were significantly reduced with the combined administration of ascorbic acid as an antioxidant.

\section{RECOMMENDATIONS}

Depending on the results of this study, the following guidelines are recommended:

1- Dietary intake of ascorbic acid supplements with increased intake of food and fruits rich in ascorbic acid is very essential as it works as a potent antioxidant that can reverse oxidative damage inside the testicular tissue induced by ethanol.

2-Widespread public education regarding the health hazards of chronic ethanol intake with a special concern about its reproductive toxic effects.

3-Increase awareness among society for early detection of addicts through attending workshops about addiction, regular screening test especially among teenagers.

\section{REFERENCES}

Aitken RJ and Roman SD (2008):

Antioxidant Systems and Oxidative

Stress in the Testes, Adv Exp Med Biol, 636 (1):154-171.

Alcohol and Drug Use Collaborators (2016): Alcohol Use and Burden for 195 Countries and Territories, 19902016: a systematic analysis for the Global Burden of Disease Study, 5(12):987-1012.

Bancroft JD and Gamble M (2008): Fixatives. In: Theory and Practice of Histology Techniques. 6th (Ed). Churchill Livingstone, Elsevier, China, $72-75$.

Chattopadhyay A, Biswas S, Bandyopadhyay D et al. (2003): Effect of Isoproterenol on Lipid Peroxidation and Antioxidant Enzymes of Myocardial Tissue of Mice and Protection by Quinidine. Molecular and Cellular Biochemistry, 245: 43-49.

Dosumu OO, Osinubi AAA and Duru FIO (2014): Alcohol Induced Testicular Damage: Can Abstinence Equal Recovery? Middle East Fertility Society Journal, 19(3):221-228.

Ebugosi R S, Okaka A N, Onochie A U, et al. (2017): Histopathological Effects of Maternal Alcohol Consumption in the Pups of Albino Rats. European Scientific Journal: 13(21) 36-38.

Eid N, ItoY and Otsuki Y (2012): Enhanced Mitophagy in Sertoli Cells of Ethanol-Treated Rats: Morphological Evidence and Clinical Relevance. J Mol Hist , 43:71-80.

Fernandes GS, Fernandez CD, Campos KE, et al. (2011): Ascorbic Acid Partially Attenuates Male Reproductive Deficits in Hyperglycemic Rats. Reprod Biol Endocrinol., 9(1):100.

Greenberg R S, Daniels R S, Flanders WD, et al. (1996): Diagnostic Testing. 
In: Medical Epidemiology. McGrawHill, New York, NY, 3rd ed., chapter (4): 77-89.

Harikrishnan R, Abhilash PA, Syam D S, et al. (2013): Protective Effect of Ascorbic Acid against Ethanol-Induced Reproductive Toxicity in Male Guinea Pigs. Br J Nutr; 110(4):689-98.

Korkmaz A \& Kolankaya D (2009): The Protective Effects of Ascorbic Acid against Renal Ischemia-Reperfusion Injury in Male Rats. Ren Fail; 31: 36 43.

Lohr RH, Wachter RM, Goldman L, et al. (2005): Acute Alcohol Intoxication and Alcohol Withdrawal. Hospital medicine (2nd ed.), Lippincott Williams \& Wilkins, Philadelphia: 234-244.

Macdonald IO, OlusolaOJ and Osaigbovo UA(2010): Effects of Chronic Ethanol Administration on Body Weight, Reduced Glutathione (GSH), Malondialdehyde (MDA) Levels and Glutathione-s-transferase Activity (GST) in Rats. New York Science Journal, 3(4): 29-35.

Maneesh M, Jayalekshmi H, Dutta S, et al. (2005): Effect of Chronic Ethanol Administration on Testicular Antioxidant System and Steroidogenic Enzyme Activity in Rats. Indian J Exp Biol., 43(5):445-449.

Maunsbach AB and Afzelius BA (1999): Biomedical Electron Microscopy: Illustrated Methods and Interpretations ( $1^{\text {st }}$ Ed.), Academic Press, Son Diego.

Mirzaei A, Mirzaei $\mathbf{N}$ and Alamdari MM (2015): Effects of Chronic Ethanol Consumption on Biochemical Parameters and Oxidative Stress on Rat. Indian Journal of Science and Technology, 8(25).
Picard M, Rossier C, Papasouliotis O, et al. (2008): Bioequivalence of Recombinant

Human FSH and Recombinant Human LH in a Fixed 2:1Combination: Two Phase I, Randomised, Crossover Studies. Curr Med Res Opin, 24(4): 1199-208.

Shalan MG, Abd Ali W and Shalan AG (2007): The Protective Efficacy Of Vitamins (C And E), Selenium And Silymarin Supplements Against Alcohol Toxicity. World Rabbit Sci., 15: $103-110$.

Siervo GE, Vieira HR, Ogo FM, et al. (2015): Spermatic and Testicular Damages in Rats Exposed to Ethanol: Influence of Lipid Peroxidation but not Testosterone. Toxicology, 1; 330: 1 8.

Takeda k, Yamuchi M, Ohata M, et al. (2003): Association between Testicular Atrophy and Muscle Atrophy after Ethanol Administration., 50: 37 - 43.

Tripathi RP, Singh B, Bisht SS, et al. (2009): L-Ascorbic Acid in Organic Synthesis: An Overview. Current Organic Chemistry, 13, 99-122.

Waly MI, Al-Attabi $Z$ and Guizani N(2015): Low Nourishment of Ascorbic Acid Induces Glutathione Depletion and Oxidative Stress in Healthy Young Adults. Prev Nutr Food Sci.; 20(3): 198-203. 




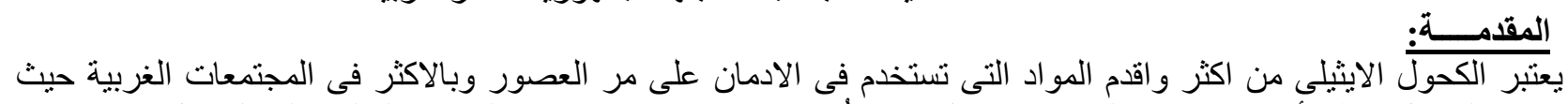

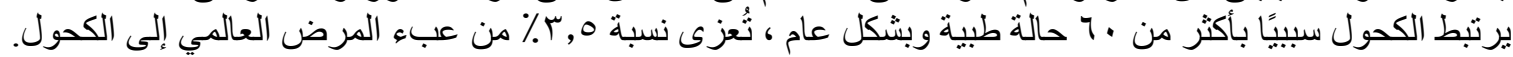

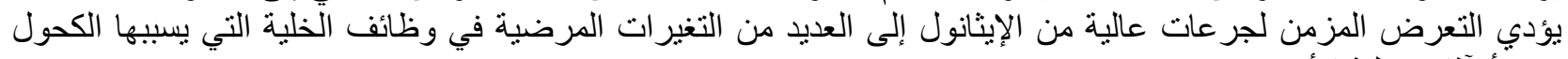

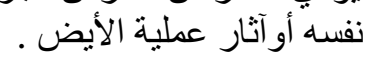
يعتبرحمض الاسكور بيك من الفيتامينات التى تعادل المركبات الضارة وتحسن القدرة المضادة للأكسدة للخلية أو الأنسجة.

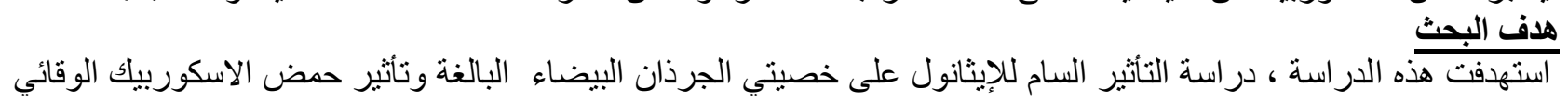
خطة البحث هذه السمية. ثن اجر أب التجربة على أربعين من الجرذان الذكور البيضاء البالغة حيث ثم تقسيمهر عشوائيا الى اربع مجموعات كل مجموعة عشرة جرذان : ع ألجربة المجمو عة الاولى (المجمو عان عة الضابطة) : لا تأخذ اى علاج (ماء مقطرفقط) الذى استخدم فى اذابة الايثانول وحمض الاسكوربيك

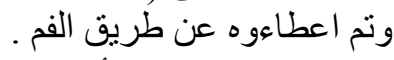
المجمو عة الثانية (لا تأخذ اع علاج أق ):هذه المجمو عة تم اعطاءها حمض الاسكوربيك جر عة واحدة يوميا ( . . (مجم/ جرذ/اليوم) عن طريق الفم.



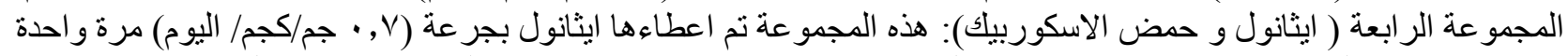

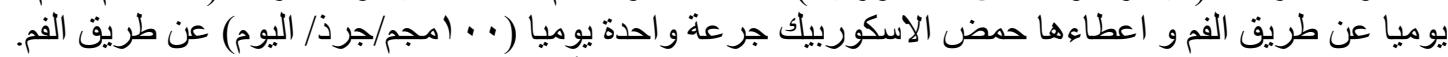

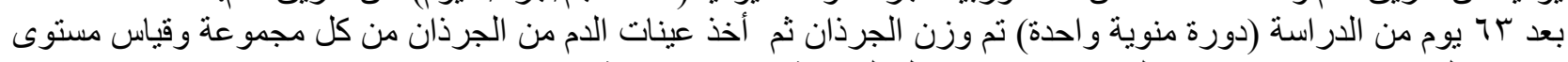



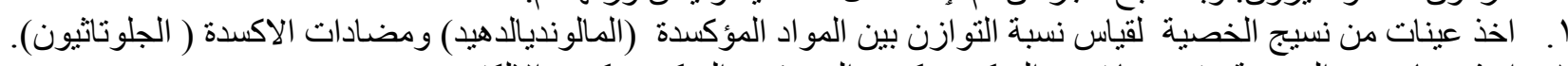



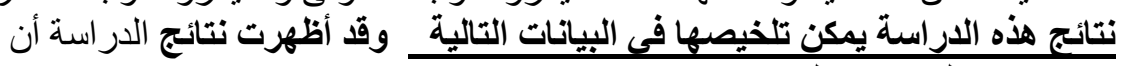



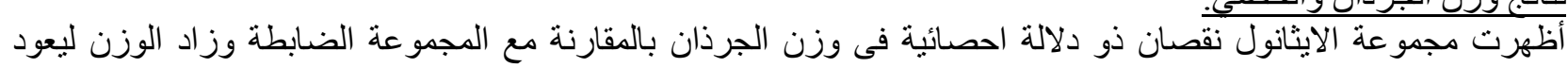

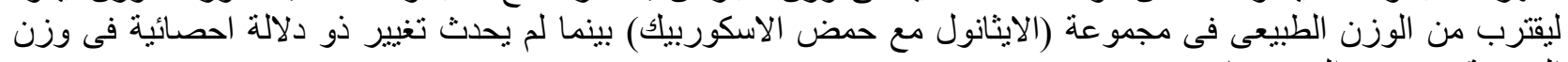

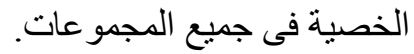

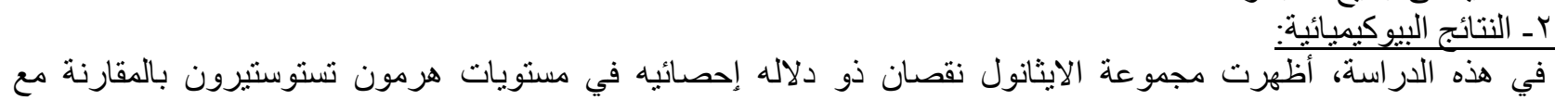

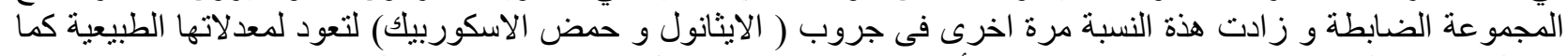

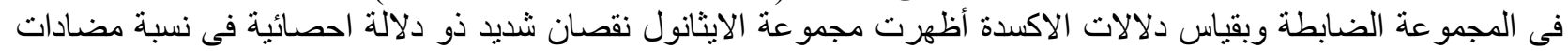

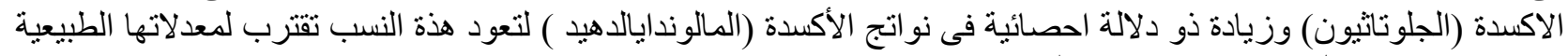



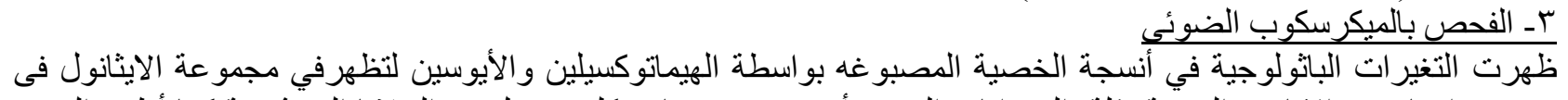

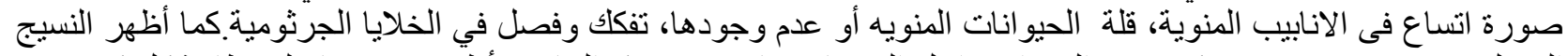



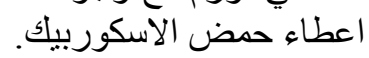
r-الفحص بالميكرسكوب الأككروباث الكترونى 
كانت هذه التغييرات في مجموعة الايثانول عبارة عن وجود خلايا غبر منتظمة الثكل (خلابا سيرتولى، خلايا ايديغ، الخلايا الضامه) مع وجود العديد من الفجوات و الحويصلات داخل جميع الخلايا و التى أظهرت تحسنا ملحوظانيا بشكل كبير عند اعطاء حمض الاسكوربيك.



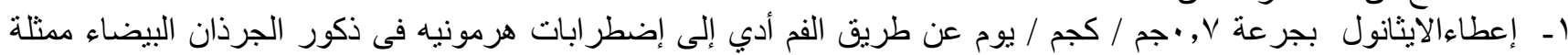

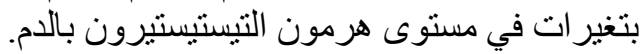



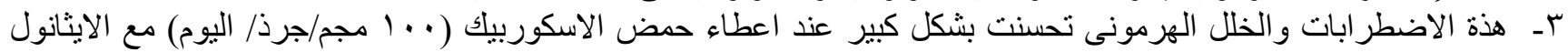

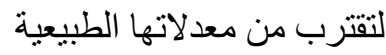
التوصيات:



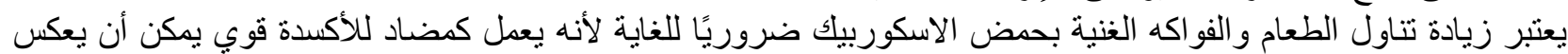





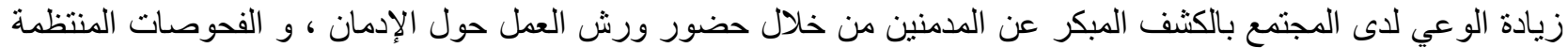

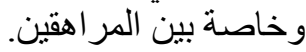

